\title{
DETERMINING FACTORS FOR MARKETING SUCCESS IN ENDEK AND EMBROIDERED TEXTILE INDUSTRY THROUGH THE INTEGRATION OF ENTREPRENEURSHIP ORIENTATION AND CUSTOMER RELATIONSHIP MARKETING IN MARKETING CAPABILITIES
}

\author{
I Gede Rihayana, Putu Pradiva Putra Salain, \\ Nyoman Resa Adhika
}

\begin{abstract}
The research on the integration of entrepreneurial orientation and customer relationship marketing in building and strengthening marketing capabilities to achieve marketing success in the endek and embroidered woven fabric handicraft industry in Denpasar City was carried out in all businesses that produce and sell woven and embroidery fabrics, and are listed in the Directory of Service Denpasar City Industry and Trade in 2016. Woven and embroidery businesses are spread in four districts with a total of 55 business units. The sample of this study is all members of the population, and placed the owners/managers of woven and embroidery fabrics as the target of the respondents. This research is a research survey using a questionnaire as the main research instrument. In addition, this study also uses independent interviews with key informants to support or explore findings from the results of the quantitative analysis. The research data were analyzed using Structural Equation Modeling (Smart-PLS), where the results showed that entrepreneurial orientation had an effect on marketing performance, but entrepreneurial orientation had no influence on marketing capabilities. Also, customer relationship marketing had an influence on marketing performance and marketing capabilities, while marketing capabilities have an influence on marketing performance.
\end{abstract}

Keywords: entrepreneurial orientation, customer relationship marketing, marketing capabilities, marketing performance

\section{A. Introduction}

The endek woven fabric and embroidery craft industry is one of Bali's increasingly popular mainstay in the creative industries (Putra, 2009). The endek

\footnotetext{
*Corresponding Author.

e-mail: igederihayana@unmas.ac.id
} 
fabric and kebaya embroidery business is generally in small and medium scale, which always considers modern design but is still based on local values and Balinese culture with distinctive colors, motifs, and designs.

The endek fabric and embroidery industry in Denpasar City is the dominant business unit compared to other regencies in the Bali Province. As the development of the city of Denpasar is creative and cultured, the Denpasar city government is increasingly improving programs for the development of its creative economy industry, especially the endek and embroidery fabric industry (Putri et al., 2015). The support of the Denpasar City government was realized by building a center for developing endek fabric designs and cultivating uniforms from endek fabrics for government and private institutions (Antari and Jannah, 2015). However, the marketing coverage of the endek weaving and embroidery handicraft industries still tends to dwell on the domestic market, so that the resulting output is still absorbed by the market in a relatively small scale. In addition, the inclusion of various types of competing products from outside of Bali (such as batik and clothing from China) presents additional burden for endek weaving and Balinese embroidery entrepreneurs in maintaining their business (Putra, 2009).

Lukiastuti (2012) argues, the marketing world of Indonesia and the world will be increasingly dynamic, which is characterized by global competition. The existence of significant change and uncertainty in the environment forces the industry to keep innovating so that the company can stabilize and com on top of the competition. It is also a fact that entrepreneurs in the endek weaving and embroidery handicraft industry that are unable to control the market will experience bankruptcy. This is in accordance with the data of the Desperindag of Denpasar City in 2016, as the number of business units in the endek fabric and embroidery industry into Denpasar City from 2012 to 2015 fluctuated and tended to decline (Figure 1). In 2015, there was quite a severe decline as much as 16.13 percent, with 62 businesses in 2014 dropping to 52 businesses in 2015 .

Marketing is a major problem that is mostly faced by small and medium scaled entrepreneurs (Andriani, 2012). Endek fabric and embroidered kebaya entrepreneurs, who are generally small and medium scale, tend to carry out limited marketing activities, and thus tend to be less competitive than their competitors. This decline in marketing performance was due to a decline in 
I Gede Rihayana, Putu Pradiva P.S., Nyoman Resa A. / Determining Factors for Marketing Success in Endek and Embroidered Textile Industry

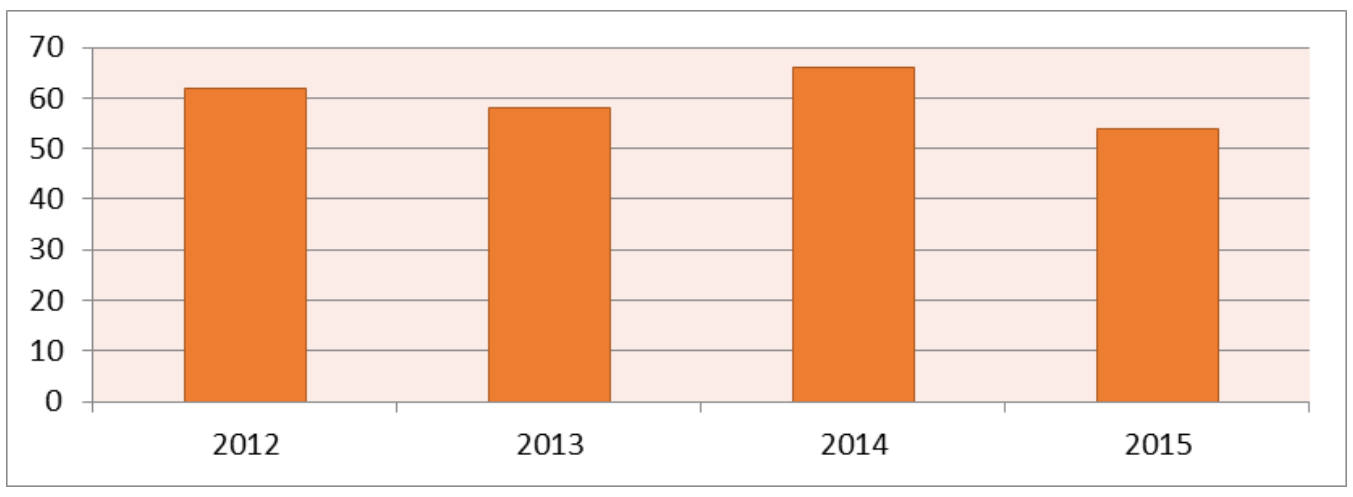

Source: Denpasar City Industry and Trade Office (2016)

Figure 1 Development of Endek Fabric and Embroidery Industry in Denpasar City in 2012-2015

market control as a result of increasingly competitive competitors' marketing maneuvers (such as lower prices and better quality). In addition, there are substitute products and new entrants in the existing market, such as: Chinese, Thai, Malaysian, and Vietnamese garment products that have cheaper prices, good models and designs, and are innovative (Putra, 2007).

Based on this phenomenon, a significant effort is needed for the entrepreneurs of endek woven fabrics and embroidery to enrich and strengthen their marketing activities. One effort to enrich and strengthen marketing activities is through marketing capabilities (Blesa and Ripolles, 2008). Conceptually, marketing capabilities refer to the company's ability to develop and foster customer relationships, and the ability to use market intelligence to recognize external factors that might have an influence on current and future customer needs (Natt et al., 2010), and quality channel relationships (Lee and Hsieh, 2010). The development in the current marketing literature based on resource-based theory shows that marketing capability is an integrated process designed to implement a collection of resources and capabilities possessed by companies that are related to the market (Zahra et al., 2006). With marketing capabilities, it allows businesses to add value and create value for customers so that performance becomes increasingly significant (Lu et al., 2010).

Murray and Peyrefitte's (2007) research results indicate that marketing capability is the ability to have a direct impact on better performance results. 
According to Akdeniz et al. (2010), marketing capabilities are built through the learning process when marketers apply their knowledge repeatedly to identify problems and provide marketing solutions. Companies can be seen to maintain a number of positions in a market, but the most popular are related to the ability to be different based on the quality or price of a product or service (Phyra et al., 2013; Adriani, 2012).

The development of marketing capabilities is an integrated process through the incorporation of resources based on the knowledge and capabilities of the company to create superior value for customers (Barney et al., 2011). Entrepreneurship is believed to be a key capability for small and medium enterprises to achieve success (Zahra et al., 2006; Suardhika, 2012). Entrepreneurship is the ability to create something new and different through creative thinking and innovative actions to meet market needs and opportunities (Scarborough and Zimmerer, 2008; Tambunan, 2009).

In an effort to obtain knowledge and capabilities from the market as faced by entrepreneurs, they are expected to have the ability to apply management functions in accordance with the concept of entrepreneurial orientation (Covin and Wales, 2012). Covin and Wales stressed that companies with a high level of entrepreneurial orientation will always make product innovations consistently, take business risks that have been considered well, and act proactively to find knowledge and capabilities to strengthen their competitive position in the market, thereby ultimately improving their performance (Lisboa et al., 2011; Lee and Chu, 2011; Moreno and Casillas, 2008).

Research conducted by Baker and Sinkula (2009) found that entrepreneurial orientation indirectly influences business performance through innovation. This finding indicates that the success of entrepreneurial-oriented companies to win competition cannot be achieved without the (marketing) capability that they have (Morgan et al., 2012). Besides, Cristina (2014) also found that entrepreneurial companies can create competitiveness provided they have the ability to invest, create new products according to customer tastes, and build networks in the market. Meanwhile, several empirical studies have proven that entrepreneurial orientation has a direct impact on company (marketing) performance (Keh et al., 2007; Lau et al., 2007; Mahmood and Hanafi, 2013). 
In addition to entrepreneurial orientation, the determining factor in strengthening marketing capabilities is building trust, commitment, handling conflicts between entrepreneurs, networking, norms, and good communication. This attracted the attention of many researchers who called it part of customer relationship marketing (Kamakura et al., 2010). Customer relationship marketing (CRM) is essentially a relationship that refers to all marketing activities that aim to build, develop, and maintain successful and long-term relationship interactions based on beliefs, norms, and networks (Brooks and Nafukho, 2006). Through relational interaction with colleagues, friends, and clients, it provides an opportunity for companies to transform their capabilities into benefits (Cheng et al., 2012). Also, Lavado et al. (2010) states that CRM has a relationship with the development of innovation capabilities. This can be interpreted that better interwoven communication and stronger networks will lead to an increase in the company's ability to innovate. This condition may be caused by an increase in the exchange of new ideas and concepts, as well as the sharing of knowledge among members of the organization (Brooks and Nafukho, 2006). However, related to the increase in company performance, Kamakura et al. (2006) found that CRM is not very influential if there is no comprehensive service and the creation of excellence in the field of logistics accompanied by competitive tariff rates. This finding indicates that through the implementation of CRM, customer relations can be managed effectively by providing services and meeting customer needs. This capability will later contribute to profit and control of market share in a sure and sustainable manner.

New entrants are increasingly easier to enter the market and change takes place so quickly (Ismawanti, 2008). Companies that are less observant will face various problems, so for this reason management creativity is needed alongside marketing programs to be able to continue to survive in the business world (Tambunan, 2009). Such changes has inadvertently encouraged many parties (management) to produce new products aimed at attracting customers because of the very competitive environment (Keh et al., 2007). The development of unique ideas certainly requires capability in marketing, so that marketing performance can be optimal (Chang et al., 2012; Best, 2009). 


\section{B. Literature Review}

\section{Entrepreneurial Orientation}

Entrepreneurial orientation has three main characteristics, namely innovation, courage to take risks, and proactivity (Covin and Wales, 2012). According to Stam and Efring (2008), entrepreneurial orientation is shown by the extent to which top managers tend to take risks associated with their business (risk-taking dimension), to support change and innovation in order to gain competitive advantage for their company (innovation dimension), and to compete aggressively with other companies (proactive dimension).

Lisboa et al. (2011) and Covin and Wales (2012) state that innovation, risk taking, and proactivity form a unique contribution to a company's entrepreneurial orientation. Furthermore, Stam and Efring (2008) state that the entrepreneurship level of a company is the total number of the three subdimensions, where a company that is truly "entrepreneurial" will display a high level in each subdimension. In this case, the aggregate measurement of the concept of entrepreneurial orientation is based on the assumption that the three subdimensions (innovation, proactivity, and risk-taking) contribute equally to the overall level of corporate entrepreneurial orientation in all situations (Covin and Wales, 2012). Nevertheless, Moreno and Casillas (2008) state that each subdimension is also likely to make a unique or different contribution to the entrepreneurial condition of any given company.

\section{Customer Relationship Marketing (CRM)}

Customer relationship marketing (CRM) is a strategy that focuses on creating customer satisfaction and sustainable relationships by integrating several functional areas of the company to achieve competitive advantage (Chang, 2007; Nguyen et al., 2007). CRM provides data and information related to customers, including shopping behavior and habits in consuming products. These data and information are used to increase understanding on the customers and to communicate with customers in order to create value, customer satisfaction, increase customer loyalty, increase profits, and to establish long-term relationships with customers and other key stakeholders (Agrawal, 2004). Furthermore, 
Sheth et al. (2002) (in Mokodongan, 2010) states that the main activities implemented to achieve CRM goals are continuity marketing, one to one marketing, and partnering programs.

\section{Marketing Capabilities}

Marketing capabilities are expressed as an integrated process designed to gather knowledge, skills, and resources from the companies that are related to market needs (Lee and Hsieh, 2010). Marketing capability enables businesses to have added value and value for customers, and be more competitive (Barney et al., 2011).

Capability in adopting strategic boundaries is operationalized using three constructs, which are the orientation to survive, short-term profit gain, or the creation of market position in the long run (Grawe et al., 2009). Marketing capability variables, according to Tsai and Shih (2004), measure the results obtained from the marketing mix, namely distribution networks, marketing research, and product development, pricing strategies, and promotion management. This concept is also used in empirical studies of Lee and Hsieh (2010) which focus on pricing, promotion, product development, distribution channels, and marketing research and development.

\section{Marketing Performance}

Marketing performance is a measure of achievement obtained from the overall marketing activity process of an organization (Chang et al., 2012). In addition, Best (2009: 66-67) argues that marketing performance is a market metric that records customer behavior, which in turn will be an indicator of financial performance. Kotler and Keller (2012: 136) add that marketing metrics are a set of measures that help companies calculate, compare, and interpret marketing performance. Meanwhile, Walker (2004: 56) suggests that marketing performance is a device used by management to assess and evaluate the effectiveness and returns of marketing activities, especially sales and market share. Based on the various definitions above, marketing performance is a measurement tool used to score and evaluate marketing activities of a company as a whole for a certain period, which effects can be felt directly by the customer. 
In measuring marketing performance, Best (2009) offers five main indicators, namely: growth in relative market share, mastery of market share, customer retention, and revenue per customer. In addition, the study of Grawe et al. (2009) uses main measurements that combine financial and marketing-based performance measures, namely: sales volume growth, profit margin growth, market share growth, and overall competitive position. Meanwhile, Chang et al. (2012) use marketing performance indicators, such as: financial perspective; customer perspective; internal processes; and innovation and learning.

\section{Hypothesis}

The hypotheses of this study are:

1. Entrepreneurial orientation has a positive effect on marketing capabilities (H1) and marketing performance (H2).

2. Customer relationship marketing has a positive effect on marketing capabilities $(\mathrm{H} 3)$ and marketing performance $(\mathrm{H} 4)$.

3. Marketing capability has a positive effect on marketing performance (H5).

\section{Research Method}

\section{Research Sampling}

This research is a survey research and uses a questionnaire as the main instrument to explain the relevance of the variables studied. This study also uses independent interviews with key informants to support or explore findings from the results of the quantitative analysis. This research was conducted in Denpasar's endek and embroidery fabric industry, which is spread in four sub-districts with a total sample of 55 business units.

\section{PLS Analysis Results}

Prior to analysis, a test on the empirical model of the study is done, which results are described below. 
I Gede Rihayana, Putu Pradiva P.S., Nyoman Resa A. / Determining Factors for Marketing Success in Endek and Embroidered Textile Industry

\section{a. Loading factor}

The value of loading factor (outer loading) shows the weight of each indicator as a measure of each variable. The results of loading factors from entrepreneurial orientation, CRM, marketing capabilities and marketing performance variables are shown in Table 1.

Table 1 Convergent Validity Test Results (Outer Loading)

\begin{tabular}{|c|c|c|c|c|}
\hline Variables & $\begin{array}{l}\text { Entrepreneurial } \\
\text { Orientation (X1) }\end{array}$ & CRM (X2) & $\begin{array}{c}\text { Marketing } \\
\text { Capability } \\
\text { (Y1) }\end{array}$ & $\begin{array}{l}\text { Marketing } \\
\text { Performance } \\
\text { (Y2) }\end{array}$ \\
\hline $\mathrm{X} 1.1$ & 0.869 & & & \\
\hline $\mathrm{X} 1.3$ & 0.810 & & & \\
\hline $\mathrm{X} 2.1$ & & 0.917 & & \\
\hline $\mathrm{X} 2.2$ & & 0.869 & & \\
\hline $\mathrm{X} 2.3$ & & 0.852 & & \\
\hline Y1.1 & & & 0.712 & \\
\hline Y1.2 & & & 0.740 & \\
\hline $\mathrm{Y} 1.3$ & & & 0.524 & \\
\hline Y1.4 & & & 0.799 & \\
\hline Y2.1 & & & & 0.904 \\
\hline Y2.2 & & & & 0.950 \\
\hline Y2.3 & & & & 0.866 \\
\hline Y2.4 & & & & 0.674 \\
\hline
\end{tabular}

The test results in Table 1 above show that the Cronbach's coefficient efficient alpha values have values above 0.6 , which can be said to be reliable, except for variable X1.2. Therefore, that variable is excluded from the research construct.

\section{b. Discriminant Validity}

Discriminant validity aims to compare the values of the square root of variance extracted for each construct. The results of discriminant validity are presented in Table 2 . 
Table 2 Discriminant Validity Test Results

\begin{tabular}{lcc}
\hline \multicolumn{1}{c}{ Variables } & $\begin{array}{c}\text { Average Variance } \\
\text { Extracted (AVE) }\end{array}$ & Information \\
\hline Entrepreneurial Orientation & 0.705 & Valid \\
Customer relationship marketing & 0.704 & Valid \\
Marketing Capabilities & 0,591 & Valid \\
Marketing Performance & 0.731 & Valid \\
\hline
\end{tabular}

The test results in Table 2 show that all AVE roots in the research variable have values greater than 0.5 . So it can be concluded that this measurement meets the requirements of discriminant validity.

\section{c. Composite reliability}

Composite reliability aims to measure the internal consistency of construct forming indicators. The results of the composite reliability test are presented in Table 3.

Table 3 Composite Reliability Test Results

\begin{tabular}{ll}
\hline \multicolumn{1}{c}{ Variables } & $\begin{array}{l}\text { Composite } \\
\text { Reliability }\end{array}$ \\
\hline Entrepreneurial Orientation & 0.827 \\
Customer relationship marketing & 0.911 \\
Marketing Capabilities & 0,791 \\
Marketing Performance & 0.915 \\
\hline
\end{tabular}

\section{d. Structural Model Evaluation (GoF)}

The structural model of Goodness of Fit $(\mathrm{GoF})$ on the inner model uses the value of $\mathrm{Q}^{2}$ predictive-relevance $\left(\mathrm{Q}^{2}\right)$ to test the variables used in the model too determine the amount of influence exogenous variables have on endogenous variables. The value of $\mathrm{R} 2$ for each endogenous variable in this study can be seen in Table 4 below. 
I Gede Rihayana, Putu Pradiva P.S., Nyoman Resa A. / Determining Factors for Marketing Success in Endek and Embroidered Textile Industry

Table $4 \mathbf{R}^{2}$ Value of Endogenous Variables

\begin{tabular}{lc}
\hline \multicolumn{1}{c}{ Dependent Variables } & R-square \\
\hline Marketing Capabilities (Y1) & 0,456 \\
Marketing Performance (Y2) & 0,332 \\
\hline
\end{tabular}

$\mathrm{Q}^{2}$ predictive-relevance values are obtained using the following formula:

$\mathrm{Q}^{2}=1-\left(1-\mathrm{R}_{1}^{2}\right)\left(1-\mathrm{R}_{2}^{2}\right)$

$\mathrm{Q}^{2}=1-(1-0,513)(1-0,332)$

$\mathrm{Q}^{2}=1-0,325$

$\mathrm{Q}^{2}=0,675$

The calculation results show a predictive-relevance value of $0.675(>0)$. This means that $67.5 \%$ of the variation analyzed in the research model can be explained in its entirety by the research model and the remaining $32.5 \%$ is explained by variables outside the research model.

\section{Results and Discussion}

\section{Hypotheses Testing Results}

The testing of this hypothesis is done to find out how much direct and indirect influence exists between variables in this study.

Table 5 Research Hypotheses Testing

\begin{tabular}{|l|c|c|c|}
\hline \multicolumn{1}{|c|}{ Variables Path Test } & $\begin{array}{c}\text { Path } \\
\text { Coefficient }\end{array}$ & t- Statistics & Information \\
\hline $\begin{array}{l}\text { Entrepreneurial Orientation } \rightarrow \text { Marketing } \\
\text { Capabilities }\end{array}$ & 0.480 & 5.134 & Sig \\
\hline $\begin{array}{l}\text { Entrepreneurial Orientation } \rightarrow \text { Marketing } \\
\text { Performance }\end{array}$ & -0.245 & 0,890 & Non Sig \\
\hline $\begin{array}{l}\text { Customer Relationship Marketing } \rightarrow \\
\text { Marketing Capabilities }\end{array}$ & 0.297 & 3.284 & Sig \\
\hline $\begin{array}{l}\text { Customer Relationship Marketing } \rightarrow \\
\text { Marketing Performance }\end{array}$ & 0.411 & 3.122 & Sig \\
\hline $\begin{array}{l}\text { Marketing Capabilities } \rightarrow \text { Marketing } \\
\text { Performance }\end{array}$ & 0.387 & 2.707 & Sig \\
\hline
\end{tabular}


Based on the results of the hypothesis test above, it can be explained that there are five paths of analysis that connect directly between the research variables, where the results of the study show that there are four significant relationships and one relationship that is not significant between the research variables in the study. In connection with the integration of Entrepreneurial Orientation and customer relationship marketing in the Marketing Capabilities to build Marketing Performance in the endek woven and embroidered textile handicraft industry of Denpasar City can be presented in Figure 2 below.

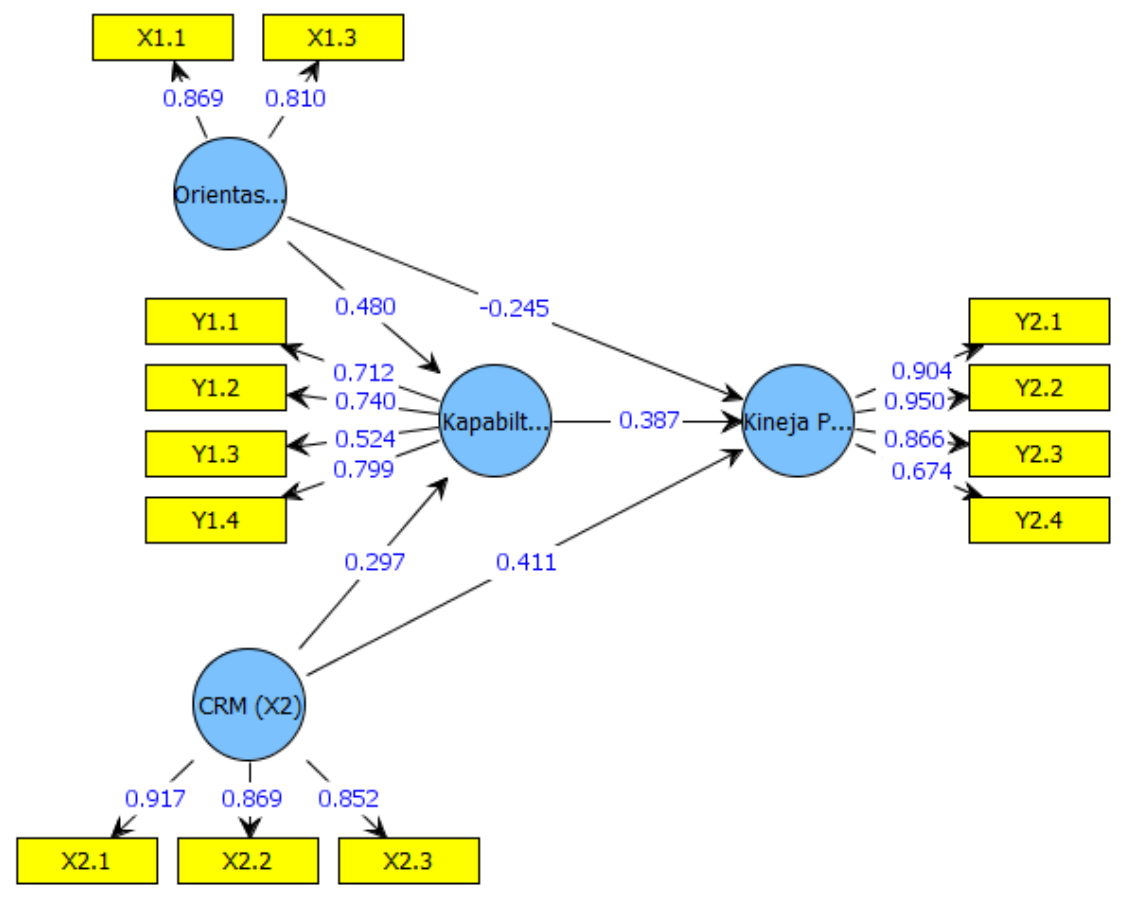

Figure 2 PLS Output Results

\section{Discussion of Research Results}

Entrepreneurial Orientation has a significant positive effect on Marketing Performance with a path coefficient of $0.480(t=-5.134)$. That is, the first hypothesis (H1) cannot be rejected. The meaning is that the better the application of Entrepreneurial Orientation, the more able the employees will be to improve their Marketing Performance significantly. The results of this study 
confirm the results of the research by Zahra et al (2006) and Suardhika (2012), that entrepreneurship is believed to be a key capability for small and medium enterprises in achieving success.

Entrepreneurial Orientation does not have a significant positive effect on Marketing Performance with a path coefficient of $-0.245(t=0.890)$. That is, the second hypothesis (H2) is rejected. The results of this study do not confirm the results of the study of Keh et al. (2007), Lau et al. (2007) and Mahmood and Hanafi (2013) that Entrepreneurial Orientation has a direct impact on company performance (marketing).

Customer relationship marketing was found to have a significant positive effect on Marketing Performance. This can be seen from the path coefficient, which is equal to $0.297(\mathrm{t}=3.284)$. That is, the third hypothesis $(\mathrm{H} 3)$ is accepted. The meaning is that the better the application of customer relationship marketing, the more employees will be able to help in improving the Marketing Capabilities. This is in line with the research of Cheng et al. (2012) that relational interactions with colleagues, friends, and clients provide opportunities for companies to transform capability into profits. Similarly, Lavado et al. (2010) state that customer relationship marketing has a relationship with the development of innovation capabilities.

Customer relationship marketing has a significant positive effect on Marketing Capabilities. This can be seen from the path coefficient, which is equal to $0.411(t=3.122)$. That is, the fourth hypothesis $(\mathrm{H} 4)$ is accepted. The meaning is that the better the customer relationship marketing, the more capable employees will be in improving Marketing Performance. The results of this study do not confirm Kamakura et al. (2006) regarding the improvement of company achievements where the results of research conducted found that CRM is not very influential if there is no comprehensive service and creation of excellence in the field of logistics accompanied by competitive tariff rates.

Marketing Capabilities have a significant positive effect on Marketing Performance. This can be seen from the path coefficient which is equal to 0.387 and t-statistics 2.707> 1.96. That is, the fifth hypothesis (H5) is accepted. The meaning is that better Marketing Capabilities gives better help in increasing Marketing Performance. This is in line with the results of the research conducted by Zahra et al (2006), Akdeniz et al (2010) and Murray and Peyrefitte's (2010) 
studies state that Marketing Capabilities have a direct impact on better performance results.

\section{Research Implications}

The research implications that can be drawn from the research are the lack of opportunities given to entrepreneurs/managers of endek embroidery industries to introduce their products through exhibitions, the lack of weavers employed because entrepreneurs still use traditional weaving systems, and the price of raw materials which are considered to be too expensive.

On the other hand, the implications of this research from an academic point of view is that this research can be expanded based on the problems obtained from previous researches so that in the future it can help entrepreneurs or managers of endek weaving and embroidery industry to further develop their business.

\section{E. Conclusion and Suggestions}

Some conclusions that can be taken from this study are as follows: The development of product design by the company, efforts to produce products that suit the tastes of customers, and the creation of new breakthroughs in the production process have not been able to significantly improve Marketing Performance. The implementation of customer relationship marketing can actually help in increasing Marketing Performance. The selection in the use of promotional media needs to be improved. Marketing Performance needs to be further improved so that the company is able to further develop.

Based on the conclusions and the results of research on the integration of Entrepreneurial Orientation and customer relationship marketing in building and strengthening marketing success in the endek woven fabric and embroidery industry in Denpasar City, some suggestions can be given. First, the company must be able to improve the performance of the marketing system so that the products owned can be marketed more optimally. Second, the company must make improvements in terms of service, so that consumers can be better served in order to provide comfort and satisfaction in shopping. Third, companies must 
make changes in their promotion system in order to be more targeted and to be able to give a different impression through the consumers' perspective. Fourth, companies must make improvements to the marketing sector of the company to be able to expand the sales network. The suggestion for further research is how researchers are able to assist in implementing the concept of Entrepreneurial Orientation for endek weaving and embroidery industry entrepreneurs through the implementation of training and mentoring so that the owners / managers of this endek weaving and embroidery business will be able to further develop their business in the future.

\section{F. References}

Adriani, N. 2012. Model Hubungan Modal Sosial, Kompetensi Pemasaran (Marketing Intelligence dan Marketing Innovation dalam Memengaruhi Marketing Performance. Jurnal Aplikasi Manajemen, 10(1), 50-59.

Agrawal, L.M. 2004. Customer Relationship Management (CRM) \& Corporate Renaissance. Journal of Service Research, 3(2), 149-167.

Akdeniz, M.B., Gonzalez-Padron, T., and Calantone, R.J. 2010. An Integrated Marketing Capability Benchmarking Approach to Dealer Performance through Parametric and Nonparametric Analyses. Industrial Marketing Management, (39), 150-160.

Antari, N.P.B.W. dan Jannah, L.M. 2015. The Role of Denpasar Government in Supporting the Resources of Endek Fabric Creative Industry. Bisnis \& Birokrasi Journal, 22(1), 17-35.

Barney, J., Ketchen, D., and Wright, M. 2011. The Future of Resource Based Theory:

Revitalization or Decline? Journal of Management, 37(5), 1299-1315.

Best, R.J. 2009. Market-Based Management: Strategy for Growing Customer Value and Profitability. New Jersey: Pearson Education Inc.

Blesa, A. and Ripolles, M. 2008. The Influence of Marketing Capabilities on Economic International Performance, International Marketing Review, 25(6), 651-673.

Brooks, K. and Nafukho, M.F. 2006. Human Resource Development, Social Capital, Emotional Intelligence, Any Link to Productivity? Journal of European Industrial Training, 30(2), 117-128. 
Chang, H.H. 2007. Critical Factors and Benefits in the Implementation of Customer Relationship Management, Total Quality Management, 18(5), 483-508.

Chang, S.H., Chen, C.H., and Yu, C.H. 2012. A Study of Marketing Performance Evaluation System for Notebook Distributors. International Journal of Business and Management, 7 (13), 85-93.

Cheng, C., Chen, J.S., and Tsou, H.T. 2012. Market-Creating Service Innovation: Verification and Its Associations with New Service Development and Customer Involvement. Journal of Service Marketing, 26(6), 444-457.

Covin, J.G. and Wales, W.J. 2012. The Measurement of Entrepreneurial Orientation. Entrepreneurship Theory and Practice, 36(4), 677-702.

Cristina, Sterpu. 2014). The Marketing Entrepreneurship and the SMEs Competitiveness. Journal of Knowledge Management, Economics and Information Technology, ISSN 2069-5934.

Dinas Perindustrian dan Perdagangan Kota Denpasar. 2016. Direktori Perindustrian Kota Denpasar Tahun 2015.

Grawe, S., Chen, H., and Daugherty, P. 2009. The Relationship between Strategic Orientation, Service Innovation on Performance. International Journal of Physical Distribution \& Logistic Management, 39(4), 282-300.

Kamakura, W.A., A. Ansari, C.F.A. Mela., P. Fader., R Bodapati., P. Naik., Iyengar., P.C. Verhoef S.B. Sun, and A. Neslin. 2006. Choice Models and Customer Relationship Management. Marketing Lett. 16(3-4), 279-2.

Keh, H.T., Nguyen, T.M.T., and Ng, P.H. 2007. The Effects of Entrepreneurial Orientation and Marketing Information on the Performance of SMEs. Journal of Business Venturing, 22, 592-611.

Lavado, C.A., Cuevas-Rodríguez, G., and Cabello-Medina, C. 2010. Social and Organizational Capital, Building the Context for Innovation. Industrial Marketing Management, 39(4), 681-690.

Lau, V.P., Au, K. and Shaffer, A.M. 2007. Entrepreneurial Career Success from a Chinese Perspective: Conceptualization, Operationalization, and Validation, Journal of International Business Studies, 38, 126-146.

Lee, H. and Hsieh, S. 2010. A Research in Relating Entrepreneurship, Marketing Capability, Innovative Capability and Sustained Competitive Advantage. Journal of Business \& Ekonomi research, 12 (3), 109-119. 
I Gede Rihayana, Putu Pradiva P.S., Nyoman Resa A. / Determining Factors for Marketing Success in Endek and Embroidered Textile Industry

Lee, T.K. and Chu, W.Y. 2011. Entrepreneurial Orientation and Competitive Advantage: The Mediation of Resource Value and Rareness. African Journal of Business Management, 5(33), 12797-12809.

Lisboa, A., Skarmeas, D. and Lages, C. 2011. Entrepreneurial Orientation, Exploitative and Explorative Capabilities, and Performance Outcomes in Export Markets: A Resource-Based Approach. Industrial Marketing Management, 40, 1274-1284.

Lu, Y., Zhou, L., Garry, B. and Li, W. 2010. Capabilities as a Mediator Linking Resources and the International Performance of Entrepreneurial Firms in an Emerging Economy. Journal of International Business, 41(3), 419-436. Lukiastuti. (2012). Pengaruh Orientasi Wirausaha dan Kapabilitas Jejaring Usaha Terhadap Peningkatan Kinerja UMK dengan Komitmen Perilaku sebagai Variabel Interviewing (Studi Empiris pada Sentra UKM Batik di Sragen, Jawa Tengah). Jurnal Organisasi dan Manajemen, 8(2), 155-175.

Mahmood. O.A.Y. and Hanafi, N. 2013. Entrepreneurial Orientation and Business Performance of Women-Owned Small and Medium Enterprises in Malaysia: Competitive Advantage as A Mediator, International Journal of Business and Social Science, 4 (1), 82-90.

Mokodongan, A. 2010. Analisis Penerapan Program Customer Relationship Management Hubungannya dengan Loyalitas Pelanggan (Studi Kasus di Swiss Bell Hotel Maleosan Manado, INOVASI, 7(4), 240-271.

Morgan, A.N., Vorhies, D.W., and Katsikeas, S.C. 2012. Export Marketing Strategy Implementation, Export Marketing Capabilities, and Export Venture Performance. Journal of the Academy of Marketing Science, 40(2), 271-289.

Moreno, A.M. and Casillas, C.J. 2008. Entrepreneurial Orientation and Growth of SMEs: A Causal Model. Entrepreneurship Theory and Practice, 32, 507528.

Murray, R.S. and Peyrefitte, J. 2007. Knowledge Type and Communication Media Choice in the Knowledge Transfer Process. Journal of Managerial Issues, 19(1), 111-133.

Nath, P., Nachiappan, S., and Ramanathan, R. 2010. The Impact of Marketing Capability, Operations Capability and Diversification Strategy on Perfor- 
mance: A Resource-Based View. Industrial Marketing Management, 39, 317-329.

Nguyen, T.U.H., Newby, M., and Sherif, S.J. 2007. Strategies for Successful CRM, Implementation. Information Management \& Computer Security, 15(2), 102-115.

Phyra, S., Aron O.C., and Keo M.S. 2013. Achieving Superior SME Performance: Overarching Role of Marketing, Innovation, and Learning Capabilities. Australasian Marketing Journal, 21, 161-167.

Putra, D.P. 2009. Terang Suram Endek Bali. http://www.saradbali.com/edisi106/ seni.htm [4 April 2015].

Putri, D.H., Suardana, I.W., dan Mananda, S. 2015. Analisis Strategi Pemasaran Kain Endek Bali sebagai Industri Pariwisata Kreatif (Studi Kasus Denpasar). Jurnal IPTA, 3(2), 7-12.

Stam, W. and Elfring, T. 2008. Entrepreneurial Orientation and New Venture Performance: The Moderating Role of Intra-and Extra Industry Social Capital. Academy of Management Journal, 51, 97-111.

Suardhika, I.N. 2012. Model Integrasi dalam RBV untuk Penerapan Strategi Bersaing dan Pencapaian Kinerja Usaha (Studi pada Usaha Kecil dan Menengah di Bali). Ekuitas STIESIA Surabaya (Terakreditasi Nasional), 5 (01), 64-83.

Tambunan, T. 2009. Export-Oriented Small and Medium Industry Clusters in Indonesia. Journal of Enterprising Communities: People and Places in the Global Economy, 3(1), 25-58.

Tsai, M.T. and Shih, M.C. 2004. The Impact or Marketing Knowledge among Managers on Marketing Capabilities and Business Performance. International Journal of Management, 21(4), 524-530.

Zahra, S.A., Sapienza, H.J. and Davidsson, P. 2006. Entrepreneurship and Dynamic Capabilities: A Review, Model, and Research Agenda. Journal of Management Studies, 43(4), 917-946.

Zimmerer, T.W. and Scarborough, N.M. 2008. Essentials of Entrepreneurship and Small Business Management. Prentice Hall, Fifth Edition. 